\title{
How Islamic are young Muslim people's poems?
}

\author{
Joke Dewilde, University of Oslo
}

\begin{abstract}
In this article, I investigate poetry written by two young Muslim people during their spare time. Adopting Shahab Ahmed's (2016) understanding of Islamic in its plenitude and complexity, I ask how Islamic their texts are. The participants, Neda and Mohammed (both pseudonyms), grew up in Islamic countries where they were socialised in faith literacy practices, including practices around sacred and devotional texts, before moving to Norway in their teens. The data used for this article were collected during two linguistic ethnographies and include poems written in and outside of school, fieldnotes from classroom observations and transcripts from multiple semi-structured interviews. The interview questions concerned their poems and writing in general as well as their observations about living as Muslims in Norway. Although their poems include few or no explicit Islamic references, the findings support an argument that an Islamic lens gives meaning to the poems in terms of Islam as they engage with rather different Islamic norms and discourses. Whereas Mohammed's texts are characterised by more prescriptive discourses leaving little room for alternative interpretations, Neda's texts contain more wonder and perplexity and are thus in line with non-prescriptive discourses. I conclude by arguing that 1) the meanings of the poems are enriched in terms of Islam by viewing them through an Islamic lens and that 2) schools should provide safe spaces for young Muslims to develop their meaning-making and writing.
\end{abstract}

Keywords: Islamic poetry, Islamic art, young Muslims, faith literacy, self-exploration

\section{Introduction}

In this article, I investigate the poetry of two young Muslim people who were writing in a new country and in a language that was still relatively new to them. Mohammed and Neda (both pseudonyms) were born in Iraq and Afghanistan, respectively, and moved to Norway at the beginning of their adolescence. I analyse their text production in Norwegian and explore possible ways to understand their poetry as part of a larger Islamic textual universe, as well as address the challenges and gains of doing so. Central to my analysis is the seminal work of Shahab Ahmed (2016) and his conceptualisation of the terms Islam and Islamic, taking the adjectival form Islamic to refer to "Islam in its plenitude and complexity of meaning" (Ahmed, 2016, p. 5). Accordingly, I ask, "How Islamic are young Muslim people's poems?"

Corresponding author's email: joke.dewilde@ils.uio.no

ISSN: 1457-9863

Publisher: Centre for Applied Language Studies

University of Jyväskylä

(C) 2019: The authors

http:/ /apples.jyu.fi

http://dx.doi.org/10.17011/apples/urn.201912185425 
At the time of the study, Mohammed and Neda were both active out-of-school writers, expressing their opinions and emotions when writing poetry in Norwegian. Dominant monolingualist orientations to multilingual writing have turned to a writer's first language or "native" culture to make sense of particularities in terms of tone, style, organisation or discourse (see for example Golden \& Hvistendahl, 2015). However, more dialogically oriented researchers have questioned these forms of generalisation and essentialisation as they have asserted that creating textual differences is "a strategic and creative choice by the author to attain his or her rhetorical objectives" (Canagarajah, 2006, p. 591) rather than unconscious errors. In this article, I do not try to pin down the poets' rhetorical choices to Islam per se; rather, I attempt to apply an Islamic lens to explore what is gained or lost when trying to make sense of their poetry in terms of Islam. Canagarajah proposed that, ideally, researchers who are multilingual themselves should study writers composing in multiple languages to gain insight into how they negotiate meaning while shuttling between languages, contexts and discourses. Since I do not share Neda's and Mohammed's first languages, I restrict myself to their poetry written in Norwegian. Importantly, however, my analysis of their texts was possible only because of my ethnographic insights in terms of their at times explicit Muslim identities and commitment to Islam.

Like many children across the globe, Mohammed and Neda were socialised into faith literacy practices through some type of formal or informal afterschool education and through taking part in devotional acts. Researchers have used the term faith literacy to describe literacy practices taking place in faith-oriented settings, often but not necessarily institutionalised (Gregory, Choudhury, Ilankuberan, Kwapong, \& Woodham, 2013; Rosowsky, 2015). ${ }^{1}$ A core characteristic of faith literacy is the centrality of a text. Sacred texts (e.g., the Bible, the Guru Grant Sahib and the Qur'an) and devotional texts (e.g., poetry, song and ritual) are transmitted from the older to the younger generation often as part of ritual and ceremony and are intertwined with the acquisition of reading practices in a familiar or unfamiliar language and script. These texts and textual practices are deeply embedded in people's identity, both collective and individual (Rosowsky, 2015, p. 169). However, this traditional distinction between sacred and devotional religious texts in faith-oriented settings excludes texts written by young Muslim people in the private sphere, setting up an unfortunate religious-secular binary, which Ahmed (2016, pp. 384-386) warned against.

I will start by exploring and exemplifying Islamic art including text (Section 2) before presenting my study (Section 3) and analysing Mohammed's and Neda's writing (Section 4). I will conclude by reflecting upon the relevance of my findings for educational settings and writing instruction for multilingual students (Section 5).

\section{What is Islamic art?}

As part of a larger discussion on the concept of Islam, Ahmed (2016, pp. 5-6) claimed that prevailing conceptions view Islam as an object and Islamic as a category with clear and fixed boundaries. Further, Ahmed (2016) criticised and challenged these conceptions, as they "critically impair our ability to recognize central and crucial aspects of the historical reality of the very object-phenomenon 'Islam' that our conceptualizations seek to denote, but fall short of doing so" ( $\mathrm{p}$. 6). In his argumentative anthology entitled What is Islam? The Importance of Being 
Islamic, Ahmed supplied a coherent object of meaning that conceptualises Islam as a theoretical object and an analytical category to unpack the capaciousness, complexity and contradictions within the historical phenomenon that began with the idea and reality of Divine Communication with Muhammad, the messenger of God. The greatest challenge to such conceptualisation is precisely the great diversity of those societies, persons, ideas and practices that identified with Islam across social and historical contexts (Ahmed, 2016, pp. 8-10).

To flesh out his conceptualisation of Islam, Ahmed (2016) posed six fundamental questions. Of particular relevance for this article is the question of "whether there is such a thing as 'Islamic art,' and if there is, then what is actually Islamic about it?" (Ahmed, 2016, p. 46). Some critics (e.g. Shalem, 2012) have classified art as an expression of culture, rather than of religion, and thus not as a constitutive element of Islam, whereas others have grappled with the relationship between "unity" and "diversity" and what they have called "the myth of the unity of Islamic art" (as cited in Ahmed, 2016, p. 47). Ahmed noted that this question is particularly vexing when it comes to art objects such as winecups or figural paintings made for a widespread social practice that violates prohibitions of Qur'an-based Islamic law. The question arises: can Islamic winecups exist, or are they secular objects and therefore non-Islamic? In response to such questions, Ahmed warned against the religious-secular binary in conceptualising Islam, as it would limit Islam to its doctrinal absolutes. Instead, Ahmed argued that researchers should instead ask what the use of the qualifier adds to the meaning. Also, it is important to remember that the artist are Muslims, "speaking to and from a 'community of discourse' of Islam" (Ahmed, 2016, p. 232). Failing to call the art objects Islamic would impoverish their meaning, whereas interpreting them as Islamic enriches.

Another dichotomy when conceptualising Islam is the private-public binary. Ahmed (2016, pp. 384-386) criticised a view where art objects of societies of Muslims are categorised as simpler and less meaningful in private spaces while simultaneously more sophisticated and more meaningful in public spaces. He related the discussion to the idea and reality of the Universal Truth of Divine Creation, which is a prerequisite for the idea of higher and lower truths available to higher and lower knowers. Inherent to the Revelatory structure, differences between norms in the private and public space are not random and onedimensional but rather logical and multi-dimensional. The fact that a particular discourse or practice remains in the private space does not disqualify it from being representative of Islam; instead, an art object in the private space is merely an expression of the spatial structure of Islam.

Central in Ahmed's (2016) conception of human and historic Islam is the notion of Self and of explorative meaning-making by the Self. Critics (e.g. Robinson, 2003) may be sceptical of tying what appears to be a modern (Western) set of ideas to Islam. However, Ahmed maintained that questions about the meaning and the constitution of the Self have been central in discourses of Muslims throughout history (see also Street, 1984) and in particular as hermeneutical engagement with the phenomenon of Revelation producing "a trajectory of Self-interrogation, Selfcontemplation, Self-affirmation, Self-articulation, and Self-action as means to meaning in terms of Islam" (Ahmed, 2016, p. 330). In other words, the sense of relationship between the Self and meaning is neither a modern and Westernised idea, nor one limited to closed social circles of Sufis (Muslim ascetics and mystics) and philosophers, but rather "a widespread and normal expression and condition of 
the human and historical fact and experience of being Muslim down the centuries" (Ahmed, 2016, p. 333). Ahmed (2016, p. 335) warned against forgetting about or minimising this exploration of meaning for the Self and privileging prescriptive discourses when conceptualising Islam or when using the word Islamic.

A final, crucial question is with what source object of meaning the hermeneutical engagement of Islam is made (Ahmed, 2016, pp. 346-348). Importantly, hermeneutical engagement of Islam can occur with texts outside the Qur'an and Hadith. Ahmed argued that the Text of Revelation requires the assumption of an Unseen Reality or truth upon which to act. The Unseen Reality is thus ontologically prior to and larger than the textual product. Ahmed therefore called this dimension the "Pre-Text of Revelation" (Ahmed, 2016, p. 347). An equally important dimension to the hermeneutical engagement with Revelation is an act that is carried out in historical context (Ahmed, 2016, pp. 356-362). Ahmed (2016, p. 356) distinguished between what he called the "context" and "Con-Text of Revelation". "Context" is used when Islam enters into new contexts (for example due to migration in the 21st century), where a larger number of elements have not acquired meaning in terms of Islam. The latter refers to Muslim communities with long historical traditions, where "the hermeneutical engagements are taking place in a context whose components have largely already acquired meaning in terms of Islam - these are contexts which are already highly populated by the Islamic" (Ahmed, 2016, p. 356; italics in original). Con-Text includes the following:

epistemologies, interpretations, identities, persons and places, structures of authority, textualities and intertextualities, motifs, symbols, values, meaningful questions and meaningful answers, agreements and disagreements, emotions and affinities and affects, aesthetics, modes of saying, doing and being, and other-truth claims and components of existing exploration and meaning-making in terms of Islam that Muslims acting as Muslims have produced and to which Muslims acting as Muslims have attached themselves during the process of hermeneutical engagement with Revelation. (Ahmed, 2016, p. 356; italics in original)

In sum, the question of "what is Islamic art?" is really a question of "what does this art object mean in terms of Islam? (and how does it mean)?" (Ahmed, 2016, p. 409; italics in original). These questions should enable researchers to move beyond the secular-religious dichotomy and acknowledge the object's multiple (contradictory) values and meanings in Islam. Conceptualising Islam as hermeneutical engagement with Revelation helps develop an analytical gaze of identifying and locating Islamic norms, not in disciplinary isolation, but "as they are generated and articulated in social and discursive and praxical diffusion in the lives of Muslims" (Ahmed, 2016, p. 407; italics in original). Ahmed concluded that researchers should not only be looking for Islamic meaning in the discourses of law or in Sufism and philosophy, but "also [in] those pre-eminent registers of meaning-making and self-expression: the imaginative and fictional discourses of poetry, narrative, music and art" (Ahmed, 2016, p. 407). Similarly, we should not be locating Islamic norms in unilateral and prescriptive statements of authoritative epistemological prescription but rather "in an ongoing multilateral conversation and negotiation of the different Truth-projects undertaken by Muslims" (Ahmed, 2016, p. 408).

Thus, rephrasing Ahmed (2016), I pose the following questions in my analysis in Section 4: What do the young people's poems mean in terms of Islam? How do 
the poems mean it? What difference does it make to the poems if they possess or fail to possess meaning in terms of Islam? What does the poem gain in meaning when it is seen as Islamic poetry, and what do we gain from seeing it as Islamic; conversely, what do we and the object lose from our non-recognition?

\section{Research site and data}

Between 2013 and 2018, I conducted two linguistic ethnographic studies of the literacy practices of multilingual young people in and outside of school. ${ }^{2}$ Linguistic ethnography generally holds that language and the social world are mutually shaping and that close analysis of situated interaction provides insights into larger mechanisms constructing everyday life (Rampton et al., 2004, p. 2). In addition to the study of interaction, a well-established strand of the field concerns literacy practices, including community-based literacy research, multilingual literacy and cross-cultural literacy in particular (for an overview, see Creese, 2008, p. 233), and this study contributes to this strand. In line with a linguistic ethnographic tradition, the data in the studies at hand are fieldnotes based on classroom observations and spare-time arenas, student texts written inside and outside of school, interview transcripts from semi-structured interviews with young people and their teachers, and pictures from linguistic landscapes.

The national context of the study is Norway. While Norway is historically a Christian country, the largest non-Christian religion is Islam, with Muslims accounting for approximately 3\% of the population (Statistics Norway, 2017). Muslims and Islam receive disproportionally much attention, mostly negative, in Norwegian media (IMDi, 2009). A report from the European Commission against Racism and Intolerance (2015) indicated that Muslims are increasingly associated with terrorism and violence in Norway and that the ways Muslims are portrayed in the media seldom challenge stereotypes and generalisations.

The setting for the studies was a large upper secondary school located in the east of Norway. In the first study, I carried out one year of fieldwork in multiple mainstream classes, while my second study involved one year of fieldwork in an introduction class for newly arrived students. In both studies, the fieldwork started with observation of the general classroom activity during the first half of the year before I selected students who were active spare-time writers and followed them more closely during the second half of the year. In this article, I focus on two of the young people, Mohammed from the first study and Neda from the second study. I have chosen them because of the way they made tangential mentions of their Muslim background in our running field conversations and while the interviews on their poetry, use of technology (e.g., Qur'anic apps and Instagram) and spare-time writing sometimes produced explicit statements.

A researcher's positionality very much contributes to shaping data collection and analysis (Copland \& Creese, 2015). My positionality differed slightly in the two studies. In both studies, I clearly allied with the students and not with their teachers. For example, I would dress casually, come and go with the students, and sit together with them during breaks. At the beginning of the first fieldwork, I told the students that I was especially interested in multilingualism, and in the second study I specified that I was interested in multilingualism in combination with writing. Whereas in the first study I admitted that I had no experience in studying young people and thus was reliant on their input, I was more confident as a youth researcher in the second study. In addition, I let them know about my 
non-Muslim background and lack of expertise about Islam- and Muslim-related issues and clearly positioned the students as experts. In contrast to my previous research with teachers, the young people never gave me the impression that they felt evaluated, nor did they ask me for advice.

Early in my fieldwork, I discovered that both Mohammed and Neda used creative writing to "make sense of life around them and their own identity" (Barton, Ivanič, Appleby, Hodge, \& Tusting, 2007, p. 71). Their writings became "vehicles for self-expression and for management of life issues and of their emotions" (Barton et al., 2007, p. 71). As part of the study, Mohammed shared diary jottings and poems with me, two of them written at home and three during interviews after school hours. Neda shared eight poems, six of them written at home and two during Norwegian classes that I observed. To gain a greater understanding of their texts and the role their writing played in their lives, I interviewed them five times each over a period of five weeks. I also contacted them by phone or by Facebook or Instagram messaging several times during the analysis process to ask additional questions. Beyond questions related to their writing, I asked how they experienced living as a Muslim in Norway, including going to the mosque, listening to recitations of the Qur' an via an app and reading religious poetry on Instagram. Sometimes, I would read the poems silently to myself, or Mohammed or Neda would read them aloud on their own initiative. With poems written at home, I would ask them to situate their writing in time and space and describe the process, both generally and specifically for each poem. Very often, I would return to the poem the next time we met to direct our discussion to issues that had attracted my analytical attention while leaving space for "doubts, ambiguities and interpretative uncertainties" (Copland \& Creese, 2015 , p. 34). As a researcher, I thus took an active role in creating a certain space for writing and reflection upon writing that was different from and in the margins of ordinary school teaching. I believe this approach was crucial to understanding school and spare-time discourses regarding these particular literacy practices.

Before I started my studies, the Islamic textual universe was not a specific topic of interest; rather, it became a new focus that emerged during my fieldwork and my initial reading of my fieldnotes, interview transcripts and texts. During the second stage, I studied understandings of Islamic art (especially those by Ahmed, 2016) before returning to the Mohammed's and Neda's poems. This process is best described as abduction (Alvesson \& Sköldberg, 2009; Bruhn Jensen, 2012), constantly oscillating between the empirical data and the theoretical perspectives. Three main categories emerged: 1) the relationship with God, 2) self-exploration, and 3 ) the value of love. In the following section, I will present and analyse these categories. I will show how Mohammed's and Neda's texts may be understood in dialogue with different discourses, more or less prescriptive and explorative when making meaning in terms of Islam.

As noted in the introduction, Mohammed and Neda wrote in Norwegian using linguistic resources they were still acquiring at the time of the study. Consequently, the language in the texts sometimes deviates from the standard in terms of grammar, orthography and idiomatic expressions. These deviations occasionally made it difficult to understand their phrasing and to translate their words into English for the purpose of this article. I translated the linguistic expressions closely, sometimes at the expense of the meaning content. However, it is inevitable that some nuances were lost during this translation process. For reasons of clarity, I have sometimes added an explanation using double round brackets. 


\section{How Islamic are Mohammed's and Neda's poems?}

In this section, I explore how Mohammed's and Neda's poetry can be understood applying Ahmed's Islamic lens of a hermeneutics of Revelation (see Ahmed, 2016) and more specifically with regard to the themes of the relationship with God (4.1), self-exploration (4.2), and the value of love (4.3) relating these to larger prescriptive and exploratory societal discourses in Islam.

\subsection{The relationship with God}

The relationship between God and religious leaders is an important theme in Islamic art. For example, the Muslim devotional genre in Hindi film, Devotional Muslim, comprises films that focus on the relationship between God and key religious leaders and encourage audiences to participate in the religious belief and experience portrayed (Dwyer, 2010, p. 127). These films foreground the importance of prayer and belief in gaining divine intervention, often after having suffered and undergone hardship, substantiating the belief of adhering to a singular truth on pain of sanction. Conversely, drawing on historical and contemporary examples, Ahmed (2016, p. 278) has illustrated how a much less explored discourse of perplexity circulated in vernacular Islamic poetry as well. At the basis of perplexity is a condition of non-resolution of Truth, which is perceived as legitimate when Muslims make sense of Divine Truth.

The relationship with God is also a recurrent theme in my field conversations with Mohammed and Neda as well as in their poems. For example, during an interview, Mohammed spontaneously stated, "God and then family and then friends. That's everything for me" (fieldnote, 30 April 2014; my translation). He not only repeatedly brought up this topic in later field conversations and interviews, but he also recycled it on his Facebook page. For example, in connection with the Muslim festival Eid, he wrote the following message in Arabic: "Blessed Eid if God wills Allah is the greatest God is great and God be thanks" (my translation). Neda also reflected upon her relationship with God during spontaneous field conversations as well as planned interviews. In addition, the topic recurred in the proverbs and short poems that she posted on Instagram, such as "Allah is watching us / And Angels are writing / What we are doing".

In the following, I will explore how the two young Muslim people engage with and make sense of this theme in their poems. In Poem 1, Mohammed describes his personal relationship with God.

Poem 1. Mohammed, 1 June 2014

\author{
For det meste Gud er alt for \\ meg, her i live. Jeg føler etter han \\ etter Gud, og det er han eneste kan \\ hort meg se meg. Kan føle at \\ han er rundt meg. [uleselig] jeg ville \\ aldri ha sagt noe dumt om han \\ det er han som skapte oss. og jeg er \\ takker han at jeg er den jeg er \\ Gud betyr mye for meg. mange \\ andre her det ikke bra men man \\ må takk gud av det man her.
}

\author{
[Mostly God is everything to \\ me, here in life. I follow him \\ follow God, and it's only him who can \\ hear me see me. Can feel that \\ he is around me. [unreadable] I would \\ never have said anything stupid about him \\ it is he who created us. and I am \\ thank him that I am the person I am \\ God means a lot to me. many others \\ don't do well but you \\ have to thank god for what you have.]
}


In his relationship with God, Mohammed indicates a hierarchical structure ("it's only him who can hear me see me", lines 3-4). He also shows affinity ("Mostly God is everything to me, here in life", lines 1-2, and "God means a lot to me", line 9) and gratitude ("you have to thank god for what you have", lines 10-11) towards him. Throughout his poem, Mohammed uses the first person singular pronouns "I" and "me" except when referring to the creation of humankind; there, he uses the plural form ("us"), emphasising his personal experience and involvement. When I asked Mohammed to explain the line "many others don't do well" (lines 9-10), he stated that he was thinking about relatives in Iraq and the difficult times they went through due to the presence of and destruction caused by the Islamic State (IS) in the area. His concluding line, "but you have to thank god for what you have", is reminiscent of the way God is portrayed in Devotional Muslim films and the belief in a singular truth (Dwyer, 2010).

As in Poem 1, Mohammed describes his relationship to God as hierarchical in Poem 2.

Poem 2. Mohammed, 6 February 2015

\author{
Tema om satan \\ vi muslimer er ikke venner med satan og det er \\ ikke han heller. Jeg sier satan ingen liker han \\ og ingen ville være i næreheten av. Og var \\ gang vi er langt unna han jo bedre det er for \\ oss og bedre tanker og live i framtiden. Men \\ hois vi er i næreheten da blir det bare \\ broplemer mer og mer, og gjør at vi skal \\ glemme gud og bøn og be til vår ene Gud \\ som han er det meste for oss. Vi elsker og være i \\ nære av guden våres der finner vi gleden og \\ sover med god tanker og gode hjerte. Ingen vil \\ vekk før vi sier Gud er med deg. \\ Til å med mammaen min sier var gang jeg drar \\ ut sier hu pass på sønnen min Gud er med deg \\ sier hu, det betyer at jeg må var god og snill \\ med alle som Gud er god med alle. Gud er den \\ meste som vet hva vi er og hvem vi er med \\ og hva vi gjør.
}

\begin{abstract}
[Theme about satan
we Muslims are not friends with satan and he is not either. I say satan no one likes him and no one wants to be neare him. And ech time we are far away from him the better it is for us and better thoughts and life in the future. But if we are neare then it becomes just broblems more and more, and make that we will forget god and prayr and pray to our only God which he is the most for us. We love to be neare our god and there we find joy and sleep with good thoughts and good heart. No on wants to leave without us saying God is with you. Even my mum says ech time I go out she says take care of my son God is with you she says, that meanes I have to be good and kind with all those God is good with. God is the most we know what we are and who we are with and what we do.]
\end{abstract}

Here, Mohammed uses the first person plural pronoun "we" to a greater extent than in Poem 1. In doing so, he positions himself as part of and as showing unity with a Muslim community (e.g., "we Muslims", line 13). New here is also how this relationship permeates daily routines, such as sleeping ("We love to be neare our god and there we find joy and sleep with good thoughts and good heart", lines 21-23) and saying goodbye ("Even my mum says ech time I go out she says take care of my son God is with you she says", lines 25-27). Again, all statements draw in the same direction, leaving little room for alternative interpretations of the Divine Truth.

The question then arises: what do Mohammed's poems potentially mean in terms of Islam, and how do they mean it (see Ahmed, 2016)? Locating Mohammed's description of his relationship with God (and with Satan) in terms of Islam makes visible a certain discourse in Islam in terms of adherence to a single truth. Poem 1 has no textual references to Islam, whereas Poem 2 speaks 
more clearly to and from a community of Islam. Nevertheless, an Islamic lens could be said to enrich our understanding of the poems as it allows us to locate and identify Islamic norms and interpret the way Mohammed reflects upon his relationship with God and the consequences of his actions accordingly. Mohammed also explicitly referred to them in the interviews.

Like Mohammed, Neda explores her relationship with God in two poems. In Poem 3, she describes how her feelings are dead and that she is ready to die, whereas in Poem 4 she writes about accepting fate.

Poem 3. Neda, 31 May 2016

31 Mine følelser er død

32 Jeg vet ikke lenger

33 det som banker inne $i$

34 meg er i livet

35 Jeg ler og smiler

36 men bak det

37 smilet mitt er

38 tusen ansikt

39 Jeg er klar til å dø,

40 men jeg er ikke klar til å svare

41 Gud det

42 jeg gjorde

43 for deg

Poem 4. Neda, 19 May 2016

44 Noen ganger jeg antar det eneste

45 du kan gjøre er å akseptere at ting

46 vil vare slik at de er, og

47 du ikke kan endre skjebnen, så

$48 d u$ må bare gi opp og godta skjebne
[My feelings are dead I don't know anymore that what is knocking inside me anymore is alive

I laugh and smile

but behind that

smile is

a thousand faces

I am ready to die,

but I am not ready to answer

God what

I did

for you]

In the last lines of Poem 3, Neda portrays her relationships to God ("I am not ready to answer God what I did for you", lines 40-43); similarly, in Poem 4, she uses the noun "fate" to describe this relationship ("so you just have to give up and accept fate", lines 47-48), thus implicitly referring to God's will. In both poems, some lines may be interpreted as signs of creative and explorative actions where Neda explores reality rather than taking reality as prescription. In Poem 3 , she writes that she is not ready to answer God, which I interpret as an act of agency. In Poem 4, the collocation "I guess" in the first line is often used to mark and modify a statement or knowledge which is the result of another source (see Chafe, 1986). Both statements can be said to open up for perplexity, in line with more non-prescriptive and non-orthodoxizing discourses.

Identifying how Neda's poems are Islamic may not be straightforward as with Mohammed's. She makes no explicit textual references to Islam. As such, her poems could have been written by and appeal to any (non-Muslim) young person. However, I chose to investigate whether they mean something in terms of Islam (see Ahmed, 2016). The analysis above shows that they can be located within non- 
prescriptive and non-orthodoxizing discourses of Islam, which Ahmed (2016) acknowledged as lesser known but nevertheless important discourses in Islam.

In sum, interpreting the relationship with God in Mohammed's and Neda's poems with an Islamic lens enriches the poems as it allows us to interpret them in light of different Islamic norms and discourses. Specifically, Mohammed's portrayal appears to be more unilateral, searching for a single truth, whereas Neda's depiction contains more wonder and perplexity, making them more in dialogue with non-prescriptive discourses. This diversity is important as it highlights a complexity of how Islam and Islamic may be conceptualised by young Muslim people in Norway.

\subsection{Self-exploration}

Another historical preoccupation of Muslims is their engagement with selfexploration in terms of Islam (see Ahmed, 2016). As already noted, well-known examples in Islamic poetry are the verses of Rūmī and of Bullhē. Ahmed (2016) related self-exploration to broader meaning-making and "the involvement of the self and of the agency of the self in the ascertaining of Truth" (p.339; italics in original). He distinguished between two modes of authority that can be found throughout history: prescriptive authority and explorative authority. Ahmed (2016) noted that, whereas "the proponent of prescriptive authority views his authority as a license to prescribe to another, the bearer of explorative authority views his authority as a license to explore (by) himself" (Ahmed, 2016, p. 282; italics in original). As touched upon in the previous subsection, self-exploration is also visible in Mohammed's and Neda's poems, which I will explore further in this section.

In Poem 5, Mohammed reflects upon the lives people should be living.

Poem 5. Mohammed, 16 May 2014

49 En dag ville vi alle skjønne hva er det som

50 skjer her og hvorfor er vi her. Live er som

51 en prøve du tar på skole, enten stryker du eller

52 er en flink elev som er på skola og gjøre det

53 man får beskjed om. Hør riktig og gjør ting

54 riktig, eller til slutt angre du av det du gjør det.

55 Smil så blir alt bra kos deg med

56 de gode venner dine og en viktig sak her $i$

57 verden, du angrer aldri hois du tar live med et

58 smil, da gjør du ham som er med deg

59 glad samtidig du her det bra. Jeg sier altid

60 aldri la ting gå over dine gode venner

61 eller familie, fordi en dag sikkert blir det bra.

62 Du må gå vidre i livet. Du kan ikke bråker som

63 en gammel bil $i$ det samme stedet lev live som

64 alle de andre gjør, men på en riktig måtte og

65 riktig tid.
[One day we will all understand what is happening here and why we are here. Life is like a test you take in school, either you fail or you are a good student who is in school and does as he is told. Listen carefully and do things right, or in the end you will regret it. Smile and everything will be ok have fun with your good friends and an important thing in life, you will never regret taking life with a smile, then you will make those who love you happy at the same time as you are ok. I always say never take things out on your good friends or family, because one day things will be ok. You must go on in life. You can't make noise like an old car standing still instead live life like everybody else does, but in the right way and right time.]

The prescriptive message of the poem is evident in both content and style. The opening line "one day we will all understand what is happening here and why we are here" can be taken to refer to God's almighty authority. The next line, "Life is like a test you take in school, either you fail or you are a good student who is in school and does as he is told", signals that there is only one, correct Truth and 
thus little room for exploration. The style further emphasises the prescriptive message, including several imperative clauses, such as "Listen carefully and do things right" (lines 53-54) and "Smile and everything will be ok" (line 55). Further, when commenting on his poem during an interview, Mohammed explained how the last line, "live life like everybody else does, but in the right way and right time", illustrated a particular moral dilemma he was facing. Many of his peers participated in the russefeiring, which is a traditional celebration to mark the end of their secondary schooling in Norway. Drunkenness, which many Muslims consider unlawful, is often a part of the celebration. In considering this, Mohammed stated, "Party is ok, but like, doing something that is over the limit, Muslim rules say no, so, then it's bad time and bad place" (my translation). Mohammed elaborated that he wished to be part of Norwegian society without compromising his beliefs embedded in an Islamic worldview.

This understanding again raises questions about what Mohammed's poems means in terms of Islam, and how does it mean it (Ahmed, 2016). While he makes no explicit reference to Islam in the poem, Mohammed made an explicit link in an interview. In terms of gains regarding Islam, Mohammed's poem and statement offer insight into a young Muslim's self-exploration in relation to prescriptive Islamic norms and discourses.

Neda is also concerned with meaning-making, but in a more explorative way than Mohammed. In Poem 6, she reflects upon how people should live life.

Poem 6. Neda, 31 May 2016

66 Noen ganger tenker jeg

67 hvordan ville livet vært

68 uten anger, uten tårer,

69 uten lidelse, uten ensomhet,

70 uten hat, uten krangling

71 Hvordan ville vi vært...?

72 Andre ganger tenker jeg på

73 at uten anger, lidelse, tårer,

74 ensomhet, hat, krangling

75 Ville vi vært en kald person

76 med uten følelser

77 Vi ville vært egoistiske, bleke

78 som vi er tom for blod $i$ kroppen

79 Vi ville vært onde

80 Vi ville ikke brydd oss, fordi

81 vi er lykkelig

82 Vi ville ikke lært oss noe

83 Livet har balanse

84 Vi må leve gjennom harde og gode

85 dager
[Sometimes I think

how would life have been

without regret, without tears, without suffering, without loneliness, without hate, without fighting

How would we have been...?

Other times I think about that without regret, suffering, tears, loneliness, hate, fighting We would be a cold person with no feelings

We would be selfish, pale as if we are empty for blood in our body We would be evil We would not have cared, because we are happy We would not have taught us anything

Life has balance

We have to live through tough and good days]

Neda starts her poem with "I think", a collocation which is often used by speakers or writers to assert their own opinion about a topic (see Chafe, 1986). Moreover, she explores how life would be without certain negative feelings ("how would life have been without regret, without tears, without suffering, without loneliness, without hate, without fighting", lines 67-70). She takes the authority to explore, and she signals that there is meaning and value to be obtained from such 
exploration. Ahmed (2016) noted "that exploration itself is of value and meaning" (p. 283; italics in original). This mode of authority is central in human and historical Islam in the search for meaning and value. In a subsequent interview, Neda elaborated that she wanted people to make up their own minds instead of uncritically listening to their elders and added that she has often been criticised by family and friends for making her own choices. In the second verse, Neda repeats the feelings, concluding that we would be selfish without them. These contradictory emotions do not merely reflect a tension between legal and nonlegal norms, but "the very ethos of a lived reality comprising a plurality of evidently contradictory meanings in life" (Ahmed, 2016, p. 36). In a subsequent interview, Neda affirmed that life should always be in balance, adding that "I often- People have to choose their own life, do what they want even if it is right or wrong because we are punished by God, not by mum and dad" (my translation). Again, neither this utterance nor her poem is explicitly linked to Islam. However, interpreting the poem through an Islamic lens highlights certain non-prescriptive discourses when conceptualising Islam, which offers valuable insights into Islam.

In sum, the analyses show that self-exploration occupies a central constitutive place in Mohammed's and Neda's poems, with Mohammed drawing on prescriptive discourses and Neda on explorative discourses to conduct such Selfexploration. The analyses have shown that an Islamic lens can illustrate a breadth of what may be Islam and Islamic to young Muslim people in Norway today as evident in their self-explorative poems.

\subsection{The value of love}

The value of love is a pre-eminent topic in Islamic poetry. The most well-known type of love poetry in Islamic culture is the ghazal, a type of poem written in rhyme in the voice of a lover on the theme of loving an unattainable beloved. In the period between the 15th and the late-19th centuries, the ghazal was performed by educated Muslims at drinking assemblies which include alcohol in what Ahmed has referred to as the temporal-geographical entity of the Balkans-to-Bengal complex, stretching from the Balkans to the Bay of Bengal, including Iran, Central Asia, Afghanistan and North India, where the majority of the Muslims resided. This socially valorised literary form was a means for self-expression and selfarticulation (Ahmed, 2016, p. 32).

The most famous book of ghazals is the Dìvann of Shams-ud-Dinn Muhammad Ḥāfiz of Shīrāz (1320-ca. 1390), consisting of about 500 ghazals. Ambiguity and ambivalence are important characteristics of the Hāfizian ghazal's register. Love is at once carnal and spiritual love, and the beloved is at once a physical desire and a beautiful youth that reflects the beauty of the Divine or is simply God Himself. Ahmed (2016, pp. 35-36) noted that the language of the ghazal indexes not just a tension between legal and non-legal norms, but the very ethos of a lived reality with all its contradictions and plurality. Ahmed acknowledged an inadequate awareness of the centrality of the idea of love in Muslim historical discourse and practice, not in sharp contrast to the idea of knowledge but as a register of knowing. Specifically, Ahmed explained this idea as follows:

the experience of love is a learning experience (or an experience of learning) that teaches the lover how to identify value (i.e., what is valuable) and to constitute the human being -both as individual and as society- accordingly, in terms of those values. (Ahmed, 2016, p. 42; italics in original) 
Mohammed and Neda had no knowledge of the Hāfizian ghazals. However, in this article, I take the ghazals as an analytical example and a reminder of the complexity, the ambiguity and the ambivalence of love in an Islamic sense before turning to the poems written by Mohammed and Neda on the topic of love.

As with other Islamic writers, the value of love is an important topic in the poetry of Neda and Mohammed. In the extract of Poem 7 below, Neda writes about a girl who thinks back on her childhood.

Poem 7. Neda, 25 May 2016

\section{[...]}

86 Hvis en gang, bare en gang hun kunne gå

87 tilbake tiden, ville hun ikke endret noe. Hun

88 ville bare ha enda en sjanse for å føle alt på

89 nytt

90 I dag er hun våken fra drømmen som hun

91 aldri ville forlate

92 Hun sitter her og lever i den virkelige

93 verdenen

94 Hun forstår hva lidelse er

95 Hun forstår hva kjærlighet er

96 Hun forstår hva glede er

97 Men hun forstår ikke livet ennå $[\ldots]$

[If once, just once she could go back the time, she wouldn't change a thing. She would just have another chance to feel everything again

Today she is awake from the dream that she would never leave

She sits here and lives in the real world

She understands what suffering is

She understands what love is

She understands what happiness is

But she doesn't understand life yet]

As in Poem 6, Neda writes about contradictory emotions in life, this time in relation to those a girl experiences during her childhood. The three last lines are particularly interesting because the emotions of love and happiness are linked to knowledge ("She understands what love is; She understands what happiness is", lines 94-95). The last line concludes that, although she understands what suffering, love and happiness are, she does not understand life yet. The experience of different emotions teaches the girl in the poem about certain values in life. Applying an Islamic lens, the girl's meaning-making process could be interpreted as a way of trying to link carnal to spiritual love, that is, to the Revelation and search for Truth (Ahmed, 2016), indexing the centrality of the idea of love in historical Islamic discourse and practice, which is also what is gained in Islamic terms.

Similarly, in Poem 8, Mohammed writes about love, but he focuses on his love for his home country Iraq.

Poem 8. Mohammed, 28 May 2014

98 Ya Irak alt som skjer in der, det bare

99 gjøre oss mer og mer glade $i$ deg. Jeg borte

100 fra deg og vet så lite hvordan du er hvordan

101 du klarer og gå fram med masse din

102 triste sanne ditt, massse blø og kjærlihet er

103 ørdlag deg hva skjer inne der. Jeg savner deg

104 jeg ofte tenker på deg. Og ser opp til deg det

105 er sant at jeg dro av deg men jeg lover jeg og

106 mitt live er der tenker og tenker på deg.

107 aldri vart så såra som jeg er nå, ting man

108 blir tvingt til å gjør og dra fra deg, ønsker

109 meg bare å komme og lukte på sannda ditt og

110 vare ditt familie mitt alt det der mangler jeg

111 og treng jeg.
[Ya Iraq everything that happens in there, it just makes us love you more and more. I'm away from you and know so little about how you are how you are coping and continue with a lot your sad true you, a lot of blood and love is

destroy you what happens in there. I miss you I often think about you. And I look up to you it's true that I left you but I promise you and my life is there thinking and thinking about you. have never been so hurt as I am now, things you are forct to do and leave from you, wishing me just to come back and smell your sand and be yours my family and everything there I miss and I need you] 
In Poem 8, Mohammed makes meaning of having left his home country in a state of war and destruction. His love for Iraq is juxtaposed with feelings of hurt as well as being forced by others to leave his home behind ("a lot of blood and love is destroy you", lines 102-103, and "have never been so hurt as I am now, things you are forct to do and leave from you", lines 107-108) enforced by others. Thinking about Iraq and wanting to go back presents a moral, intellectual and existential valorisation of his home country. In a subsequent interview, Mohammed did not explicitly link his carnal love for Iraq to spiritual love in terms of Islam. However, analysing the poem in terms of Islam as hermeneutical engagement with the Revelation (Ahmed, 2016), we may identify and locate Islamic norms which are important in the life of Mohammed as a Muslim and very much in contrast to the values of IS, which he frequently talked about in other interviews (see also Poem 2). In other words, the way Mohammed experiences love for his home country may contribute to teaching him certain values embedded in Islam.

In sum, even though neither young person's poems are explicitly Islamic, Neda explores the relationship between the virtue of love and knowledge by reflecting upon the contraries inside of her, and Mohammed writes more in line with prescriptive discourses as he reflects upon contrasts between unwanted actions outside of him and the norms he knows he has to follow. These approaches add an extra dimension to the poems in terms of Islam.

\section{Discussion and concluding remarks}

Ahmed (2016, pp. 408-409) has argued that all artistic forms are produced and reproduced by a society because members in that society engage with them, giving them value and meaning. In this article, I asked to what extent these young people's poems are Islamic. Rephrasing Ahmed (2016), I posed the following questions in my analysis: What do the young people's poems mean in terms of Islam? How do the poems mean it? What difference does it make to the poems if they possess or fail to possess meaning in terms of Islam? What does the poem gain in meaning when it is seen as Islamic poetry, and what do we gain from seeing it as Islamic; conversely, what do we and the object lose from our nonrecognition?

Before answering these questions, it is important to return to Ahmed's (2016, pp. 356-362) notions of Con-Text and context. Mohammed and Neda live in Norway, which is a context that is not populated with Islamic symbols. Trying to understand potential Islamic elements in their poetry has nevertheless been a valuable task, albeit not an easy one. I found myself concerned with understanding the multiple Islamic discourses, both prescriptive and explorative, they engage with in their texts, making visible a complexity of what the category 'Islamic' may mean. Not viewing their poems as Islamic would overlook these discourses and consequently reduce the poems' meaning. Conversely, seeing the poems as Islamic enables us to take the young people's life worlds seriously and engage in dialogue with how they make sense of the world.

My analysis of Mohammed's and Neda's writing shows how their poems can be understood within an Islamic framework as they make meaning of life around them and their own identity (see Barton et al., 2007). It also brings to light different ways of being Islamic, possibly knocking down the divide between religions and between the religious and the secular, which is important 
considering the increasing intolerance towards Muslims in society (see European Commission against Racism and Intolerance, 2015; IMDi, 2009).

A final pressing question is what relevance my findings have for schools and for writing instruction for multilingual students. Research from Sweden has shown that mainstream schools silence the experiences of young Muslims (Berglund, 2009, 2017). The current curriculum for the subject Norwegian states that the subject Norwegian provides a space where students "are given the opportunity to find their own voices, utter themselves, be heard and get answers" through oral and written communication (Norwegian Directorate for Education and Research, 2013; my translation). Mohammed and Neda are both active sparetime writers who cherish this space and use it for personal reflection in Norwegian, a language that is still relatively new to them. Their poems give us unique insights into their life worlds and into how they relate to Islamic discourses in a nonIslamic country. A "safe space" (Pratt, 1991) like the one I created during my interviews can be seen as a first step in moving from the private to the public sphere. Similar spaces in schools would enable young people to explore their Islamic identities in a new country and develop their meaning-making and writing in a second language, perhaps creatively meshing other linguistic resources they bring with them (see for example Canagarajah, 2019; Evensen, 2017). Exploring the features of these spaces is a much needed avenue for future research.

\section{Acknowledgments}

I wish to thank the students who participated in the study. In addition, sincere thanks go to Senior Lecturer Nora S. Eggen of the University of Oslo, the members of the Studies of Instruction across Subjects and Competences (SISCO) research group at the University of Oslo, the members of the Diversity in Education (DivE) research group at Inland Norway University of Applied Sciences as well as the members of the Linguistic Diversity in School and Society research group for commenting on an earlier draft of this article.

\section{Endnotes}

${ }^{1}$ In contrast, the term religious literacy has most commonly referred to knowledge about religion and is thus more loosely connected to actual literacy practices (see for example Dinham \& Francis, 2016).

2 The first study was my section of the NordForsk funded project Learning Spaces for Inclusion and Social Justice: Success Stories from Immigrant Students and School Communities in Four Nordic Countries (53704), directed by Hanna Ragnarsdóttir between 2013 and 2016. The second study was my postdoctoral study Multilingual Young People as Writers in and outside of School, funded by the Department of Teacher Education and School Research at the University of Oslo between 2015 and 2018. 


\section{References}

Ahmed, S. (2016). What is Islam? The importance of being Islamic. Princeton, NJ: Princeton University Press.

Alvesson, M., \& Sköldberg, K. (2009). Reflexive methodology: New vistas for qualitative research (2nd ed.). London: Sage.

Barton, D., Ivanič, R., Appleby, Y., Hodge, R., \& Tusting, K. (2007). Literacy, lives and learning. London: Routledge.

Berglund, J. (2009). Teaching Islam: Islamic religious education at three Muslim schools in Sweden. (Unpublished doctoral dissertation). Uppsala University, Uppsala, Sweden.

Berglund, J. (2017). Secular normativity and the religification of Muslims in Swedish public schooling. Oxford Review of Education, 43(5), 524-535.

Bruhn Jensen, K. (2012). The complementarity of qualitative and quantitative methodologies in media and communication research. In K. Bruhn Jensen (Ed.), A Handbook of media and communication research: Qualitative and quantitative methodologies (2nd ed., pp. 283-301). London: Routledge.

Canagarajah, S. (2006). Toward a writing pedagogy of shuttling between languages: Learning from multilingual writers. College English, 68(6), 589-604.

Canagarajah, S. (2019). Transnational literacy autobiographies as translingual writing. Oxon: Routledge.

Chafe, W. (1986). Evidentiality in English conversation and academic writing. In W. Chafe \& J. Nichols (Eds.), Evidentiality: The linguistic encoding of epistemology (pp. 261-272). Norwood, NJ: Ablex Publishing Corporation.

Copland, F., \& Creese, A. (2015). Linguistic ethnography: Collecting, analysing and presenting data. Los Angeles, CA: Sage.

Creese, A. (2008). Linguistic ethnography. In K. A. King \& N. H. Hornberger (Eds.), Encyclopedia of language and education (2nd ed., Vol. 10, pp. 229-241). New York: Springer Science+Business Media LLC.

Dinham, A., \& Francis, M. (2016). Religious literacy: Contesting an idea and practice In A. Dinham \& M. Francis (Eds.), Religious literacy in policy and practice (pp. 3-26). Bristol: Policy Press.

Dwyer, R. (2010). I am crazy about the Lord: The Muslim devotional genre in Hindi film. Third Text, 24(1), 123-134.

European Commission against Racism and Intolerance (Ed.) (2015). ECRI report on Norway. Strasbourg: Council of Europe.

Evensen, T. (Ed.) (2017). Enslige mindreårige asylsøkere - skriver for livet [Unaccompanied minors - writing for life]. Vallset: Oplandske Bokforlag.

Golden, A., \& Hvistendahl, R. (2015). Forskning på andrespråksskriving i Skandinavia, med vekt på de norske studiene [Research on second language writing in Scandinavia, with an emphasis on the Norwegian studies]. In A. Golden \& E. N. Selj (Eds.), Skriving på norsk som andrespråk: Vurdering, opplæring og elevenes stemmer [Writing in Norwegian as a second langauge: Assessment, teaching and student voices] (pp. 231-246). Oslo: Cappellen Akademisk.

Gregory, E., Choudhury, H., Ilankuberan, A., Kwapong, A., \& Woodham, M. (2013). Practice, performance and perfection: Learning sacret texts in four faith communities in London. International Journal of Sociology of Language, 220, 27-48.

IMDi. (2009). Immigrants in Norwegian media. A report retrieved from https:// www.imdi.no/contentassets/3e937755549748368d1d9384f91e6138/immigran ts-in-norwegian-media-summary.pdf

Norwegian Directorate for Education and Research. (2013). Læreplan i norsk [Norwegian subject curriculum]. Retrieved from https://www.udir.no/k106/NOR1-05/Hele/Formaal

Pratt, M. L. (1991). Arts of the contact zone. Profession, 91, 33-40.

Rampton, B., Tusting, K., Maybin, J., Barwell, R., Creese, A., \& Lytra, V. (2004). UK linguistic ethnography: A discussion paper. Retrieved from http://www.lancaster.ac.uk/fss/ organisations/lingethn/documents/discussion_paper_jan_05.pdf 
Robinson, C. F. (2003). Islamic historiography. Cambridge: Cambridge University Press.

Rosowsky, A. (2015). Faith literacies. In J. Rowsell \& K. Pahl (Eds.), The Routledge handbook of literacy studies (pp. 169-182). London: Routledge.

Statistics Norway. (2017). Religious communities and life stance communities. Retrieved from https://www.ssb.no/en/kultur-og-fritid/statistikker/trosamf/aar

Street, B. (1984). Literacy in theory and practice. Cambridge: Cambridge University Press. 